\title{
Advanced, Low/Zero Emission Boiler Design and Operation
}

\section{Quarterly Technical Progress Report}

Reporting Period from July $1^{\text {st }}, 2003$ through September $30^{\text {st }}, 2003$

Submitted by:

Fabienne Châtel-Pélage

American Air Liquide, Chicago Research Center

5230 S. East Avenue

COUNTRYSIDE, IL 60525

Issued in October 2003

Work Performed Under Contract No.: DE-FC26-02NT41586

Submitted to:

NETL ADD Document Control BLDG. 921

U.S. Department of Energy

National Energy Technology Laboratory

P.O. BOX 10940

Pittsburgh, PA 15236-0940

Subcontractors who participated in the production of the report:

Babcock and Wilcox Research Center, 1562 Beeson Street,

P.O. Box 835,

Alliance OH 44601-2196

Illinois State Geological Survey

615 East Peabody Drive

Champaign IL 61820 


\section{DISCLAIMER}

This report was prepared as an account of work sponsored by an agency of the United States Government. Neither the United States Government nor any agency thereof nor any of their employees, makes any warranty, express or implied, or assumes any legal liability or responsibility for the accuracy, completeness, or usefulness of any information, apparatus, product, or process disclosed, or represents that its use would not infringe privately owned rights. Reference herein to any specific commercial product, process, or service by trade name, trademark, manufacturer, or otherwise does not necessarily constitute or imply its endorsement, recommendation, or favoring by the United States Government or any agency thereof. The views and opinions of authors expressed herein do not necessarily state or reflect those of the United States Government or any agency thereof. 


\begin{abstract}
This document reviews the work performed during the quarter July - September 2003. Significant progress has been made in Task 1 (Site Preparation), Task 2 (Test performance) and Task 3 (Techno-Economic Study) of the project: the site preparation has been completed, two weeks of tests have been performed and the power generating units to be compared from an economical standpoint have been selected and accurately described. In the experimental part of this effort (task1), the partners in this project demonstrated the feasibility of $100 \%$ air replacement with $\mathrm{O}_{2}$-enriched flue gas on 1.5MW coal-fired boiler. The air infiltration have been reduced to approximately $5 \%$ of the stoichiometry, enabling to reach around $70 \%$ of $\mathrm{CO}_{2}$ in the flue gases. Higher air in-leakage reduction is expected using alternative boiler operating procedure in order to achieve higher $\mathrm{CO}_{2}$ concentration in flue gas for further sequestration or reuse. The $\mathrm{NO}_{\mathrm{x}}$ emissions have been shown considerably lower in $\mathrm{O}_{2}$-fired conditions than in air-baseline, the reduction rate averaging 70\%. An additional week of tests is scheduled mid October 2003 for combustion parameter optimization, and some more days of operation will be dedicated to mercury emission measurement and heat transfer characterization. Out of the $\$ 485 \mathrm{k}$ already allocated in this project, $\$ 300 \mathrm{k}$ has been spent and reported to date, mainly in site preparation ( $\sim 215 \mathrm{k})$ and test performance $(\sim 85 \mathrm{k})$. In addition to DOE allocated funds, to date approximately $\$ 240 \mathrm{k}$ has been cost-shared by the participants, bringing the total project cost up to $\$ 540 \mathrm{k}$ as on September 30, 2003.
\end{abstract}




\section{TABLE OF CONTENTS}

DISCLAIMER

ABSTRACT

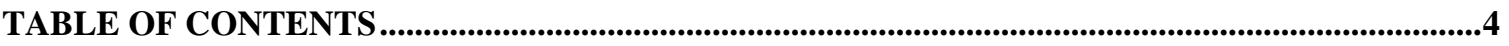

LIST OF FIGURES ..............................................................................................................................

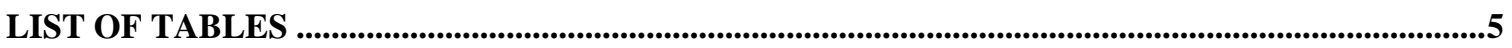

INTRODUCTION

EXECUTIVE SUMMARY ..................................................................................................................

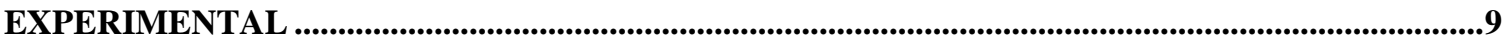

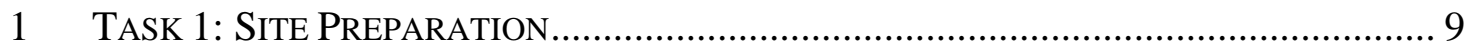

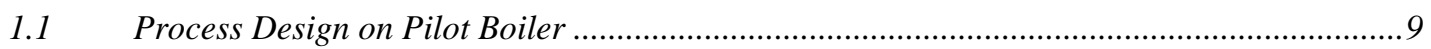

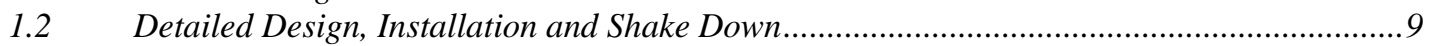

2 TASK 2: COMBUSTION AND EMISSIONS PERFORMANCE OPTIMIZATION .................. 10

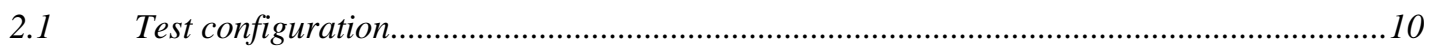

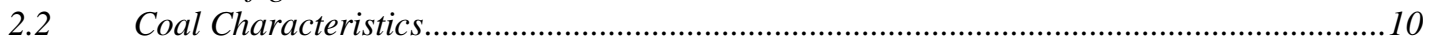

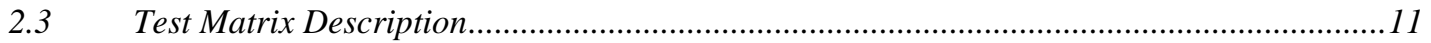

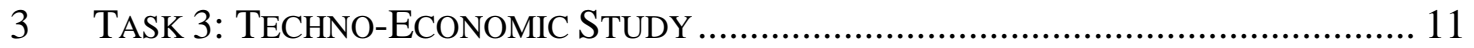

3.1 Case Study Definition: Process Cases of techno-economic analysis ....................................11

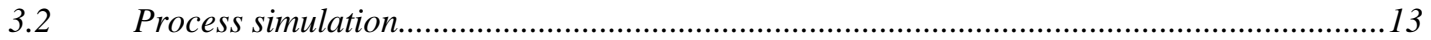

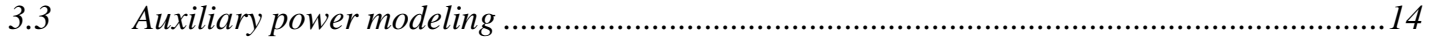

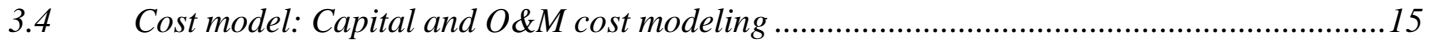

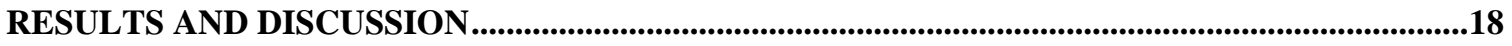

1 TASK 2: COMBUSTION AND EMISSIONS PERFORMANCE OPTIMIZATION .................. 18

1.1 Optimization of oxygen injection in the primary combustion zone ..........................................18

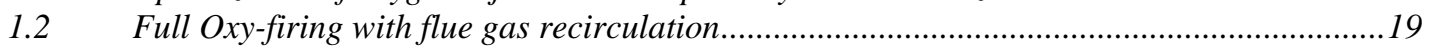

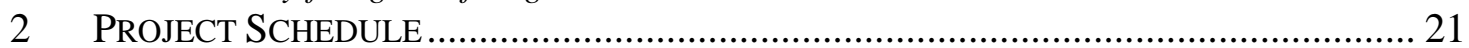

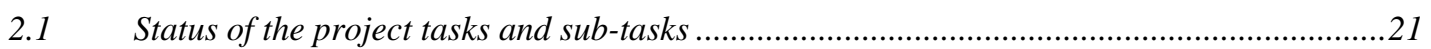

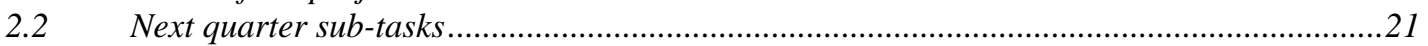

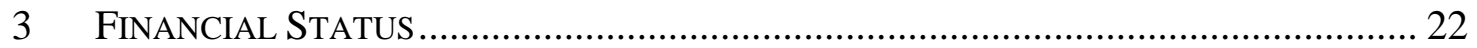

4 TASK 5: PROJECT MANAGEMENT \& REPORTING ................................................. 22

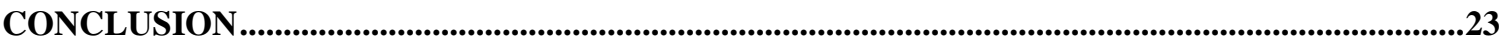

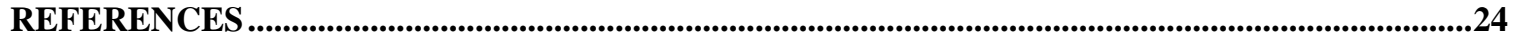

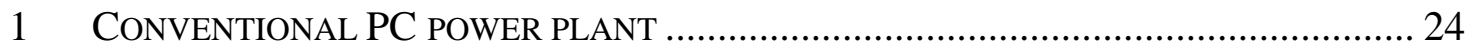

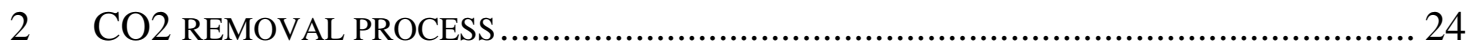

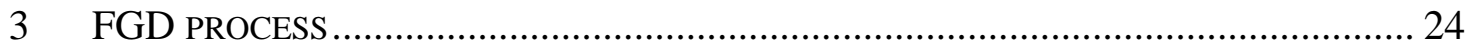

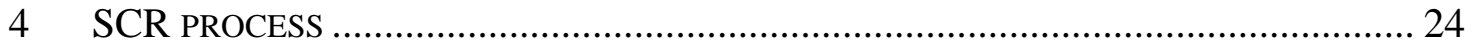

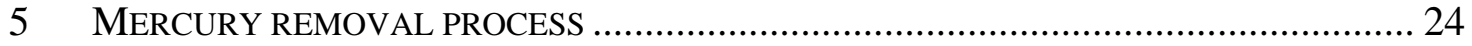

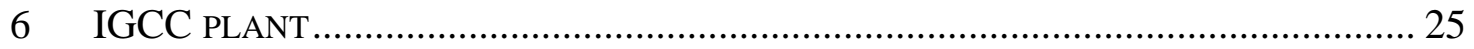

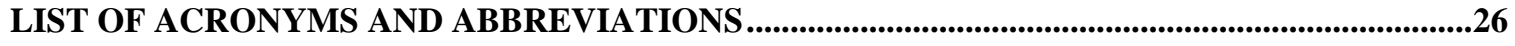

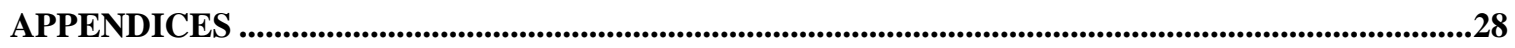

Appendix A. SBS (Small Boiler Simulator) in an Oxygen Firing Mode ..........................................29

Appendix B. New equipment and duct work (in red) installed on the SBS.......................................30

Appendix C. $\quad$ Updated modified Oxygen Skid ................................................................................. 


\section{LIST OF FIGURES}

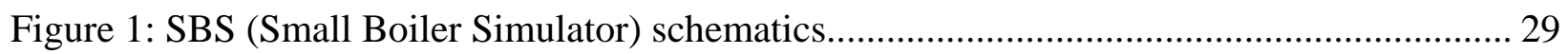

Figure 2: New equipment and duct work installed on the SBS ................................................... 30

Figure 3: Updated modified Oxygen Skid...................................................................................... 31

\section{LIST OF TABLES}

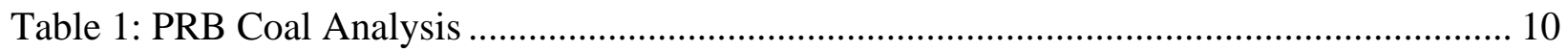

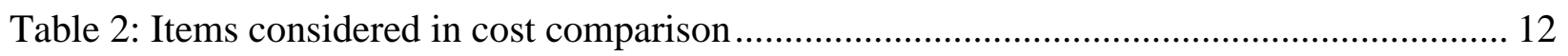

Table 3: Process Cases of the techno-economic analysis ............................................................ 13

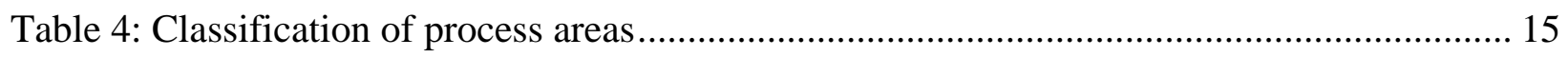

Table 5: Data levels, an example of the steam turbine generator ................................................. 16

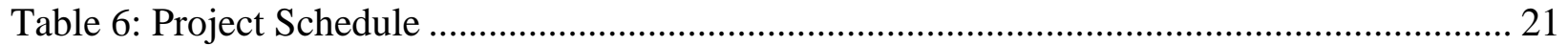

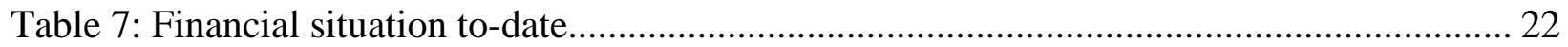

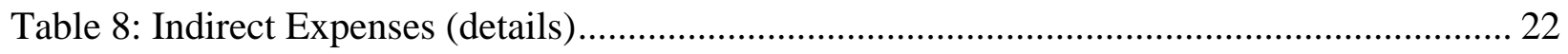




\section{INTRODUCTION}

The present report summarizes the work performed by the participants from July 1, 2003 through September 30 ${ }^{\text {th }}$, 2003 (Q3 2003).

In the previous quarters (Q1 \& Q2 2003), the site preparation (Task 1) of the experimental test campaign had been initiated through a process definition phase, most of the components required to enable the oxygen-firing mode of the pilot boiler had been purchased and the installation of boiler changes had been started. The test performance task (Task 2) was also initiated while developing a preliminary set of test series to be performed, as well as the technical-economic study (Task 3) with the definition of preliminary case study to be assessed.

In the current quarter (Q3, 2003), the site preparation (Task 1) has been completed and the final configuration of the pilot boiler, as available for experiments, is described in this report. The key part of "Combustion and Emission Performance Optimization task" (Task 2) has also been initiated and partially completed, with two weeks of tests performed as on September $30^{\text {th }}$, 2003. $100 \%$ of the combustion air has been replaced by oxygen-enriched flue gas on the 1.5MW boiler, to produce a high $\mathrm{CO}_{2}$ concentrated flue gas stream. The preliminary results are given and some trends are highlighted in the "Results and Discussion" part of this report. As part of the techno-economic study (Task 3), the accurate methodology to be applied is described, including a listing of references to be used for cost assessment of air-firing and full-oxy firing configurations, and the calculations are in progress.

This report also provides the project financial status and schedule updates. 


\section{EXECUTIVE SUMMARY}

The main effort of this quarter (July - September 2003) was primarily dedicated to Task 1 (Site Preparation), Task 2 (Test performance) \& 3 (Techno-Economic Study) of the project. The main achievements are the following:

In Task 1 (Site Preparation), the site preparation has been completed. The boiler modifications defined in the previous quarter and required to enable the complete air replacement with oxygen and recirculated flue gases have been implemented; the installation of the oxygen delivery system, including the valve skid assembly, and oxygen piping to the burner has been completed; all instrumentation insuring accurate data collection and analysis during the test period have been installed and calibrated; the coal to be burned during the first two weeks of tests has been dried and pulverized; the coal-feeding system modified to be operated in those new conditions. In addition, the required safety interlocks modifications have been implemented to enable a safe transition from air-firing operation to oxygen-firing operation and a safe operation of the boiler in this new oxygen-based configuration. The entire system has been shakedown on time (mid August 2003) enabling Task 2 initiation.

In Task 2 (Test performance), the experimental test matrix has been defined and two weeks of testing have been completed. The feasibility of $100 \%$ air replacement by $\mathrm{O}_{2}$-enriched flue gas on a 1.5MW coal-fired pilot boiler demonstrated. In particular, a smooth and safe procedure has been developed and demonstrated for the primary air replacement (air conveying the pulverized coal to the burner) with oxygen-enriched flue gas. The preliminary measurements of process characteristics while operating with 100\% oxygen and recirculated flue gas are the following:

- A stable flame has been obtained, with similar shape as in air-firing operation

- The air infiltration has been reduced from an initial level of approximately $10 \%$ of the total stoichiometry to a final level of approximately $5 \%$, thus increasing the initial $\mathrm{CO}_{2}$ content in flue gas from $15 \%$ in air-fired conditions to $55 \%$ in full-oxy conditions with $10 \%$ air infiltration, and to eventually $70 \%$ while reducing the air in-leakage down to 5\%. Alternative boiler operating procedures are expected to reduce even more the air infiltration to achieve higher $\mathrm{CO}_{2}$ concentration in flue gas for further sequestration or reuse.

- The $\mathrm{NO}_{\mathrm{x}}$ emissions have been shown considerably lower in $\mathrm{O}_{2}$-fired conditions than in airbaseline, the reduction rate averaging $70 \%$ (from an air-fired baseline at $0.42 \mathrm{lb} / \mathrm{MMBtu}$ to oxy-fired cases at 0.12lb/MMBtu).

An additional week of tests is scheduled mid October 2003 for combustion parameter optimization, and some more days of operation will be dedicated to mercury emission measurement and heat transfer characterization. 
In Task 3 (Techno-Economic Study), a detailed description of power generating units to be compared as been performed, including air-fired pulverized coal (PC) units with and without $\mathrm{CO}_{2}$ separation, oxygen-fired PC units with or without flue gas recirculation, and IGCC units. Plant capacity and equipment have been listed, the methodology to be followed for cost analysis carefully described and the first heat and mass balance along with cost calculations are currently being performed.

Out of the \$485k already allocated in this project, \$300k has been spent and reported to date (to be billed to DOE), mainly in site preparation $(\sim 215 \mathrm{k})$ and test performance $(\sim \$ 85 \mathrm{k})$. Around $\$ 180 \mathrm{k}$ will be spent in the next quarter, corresponding to the tests performed in September, the tests to be performed mid-October and the first part of the Techno-Economic study (Task 3) currently in progress. The mercury and heat transfer measurement, as well as the second part of the economical study, and also the full-oxy boiler design (Task 4) of this project will be performed once the remaining budget $(\sim \$ 300 \mathrm{k})$ will be allocated. In addition to DOE allocated funds, to date approximately $\$ 240 \mathrm{k}$ has been cost-shared by the participants, bringing the total project cost up to \$540k as on September 30, 2003. 


\section{EXPERIMENTAL}

During this reporting period, the participants have completed Task 1 (Site Preparation), have initiated Task 2 (Test performance) and have continued Task 3 (Techno-Economic Assessment) of the project.

\section{TASK 1: SITE PREPARATION}

\subsection{Process Design on Pilot Boiler}

A process design schematic incorporating major equipment and instruments has been developed in the previous quarter and the final configuration is shown in Appendices 1 \& 2 : Appendix A shows the small boiler simulator (SBS) and wet scrubber in an oxygen-fired mode. Appendix B illustrates the new equipment and ductwork (in red).

\subsection{Detailed Design, Installation and Shake Down}

In addition to the activities reported in the previous quarterly report, the following activities were performed:

- Completed the installation of the oxygen delivery system: a pre-assembled unit (including control valves, orifice plates, and pressure transducers) for the oxygen supply system had been supplied to the experimental site by June 30th and had been stored at the SBS. A certified contractor performed the modifications on the oxygen supply system. The oxygen was routed to the primary air line (after PA fan) through an Oxynator. Alternatively, the existing oxygen for the front overfire air ports was modified to introduce oxygen into the burner. Also, the oxygen supply to the overfire air ports and secondary air Oxynator was modified by the contractor. The electrical wiring was completed on site.

- Completed the Oxygen control system installation: the tuning of the oxygen supply and control system has been completed. The equipment was debugged and their accuracy was assured.

- Reviewed electrical drawings and determined instrument and safety interlock changes to the unit to receive oxygen in the primary air zone. The high oxygen concentration in the primary air line was considered a safety hazard. The safety interlocks provided the operator with an alarm at $25 \%$ oxygen concentrations in PA line and a shut down of oxygen and fuel if the oxygen concentration reaches $28 \%$.

- $\quad$ Selected and modified the burner: A B\&W DRB-4Z ${ }^{\mathrm{TM}}$ burner was selected for the tests. The burner was a $5 \mathrm{MMBtu} / \mathrm{hr}$ burner and had been designed for staged combustion operation. The burner was modified to receive oxygen in the coal nozzle through a lance or through the transition zone of the burner. Three lances were fabricated for optimization. 
- Installed and shake down the flue gas recirculation lines: the FGR lines were fabricated and installed per design specifications. The control valves were debugged and instrumentations were checked to ensure the accuracy of the FGR flow rates.

- $\quad$ Prepared the coal: Two truckloads of PRB coal were received and stored. Twenty (20) tons of coal were consequently partially dried, pulverized and stored in the SBS facility.

- $\quad$ Modified and tested a new coal-feed system: following a total system analysis performed in the previous quarter, it had been decided to modify the coal feed system to reduce the air inlet to the unit: the unit, previously using an air aspirator for feeding pulverized coal to the burner, has been equipped with a pressurized coal-feed system. The coal feed was debugged with satisfactory results. However, the oxygen fluctuation was larger than when the unit was operated with the coal aspirator. We are looking into upgrading the coal feeder to reduce the oxygen fluctuation.

- Data acquisition software was modified for oxygen enriched FGR to the primary, secondary or tertiary air lines (versus air). The software enables us to collect the data and to provide on-line operational data.

\section{TASK 2: COMBUSTION AND EMISSIONS PERFORMANCE OPTIMIZATION}

Two weeks of tests were performed during this quarter. The following subsections report the test configuration, test matrix information and coal composition, while the preliminary results of those tests are given in the next chapter of this report "RESULTS AND DISCUSSION".

\subsection{Test configuration}

\subsubsection{Facility Description}

The final pilot boiler configuration is described in Appendices 1 \& 2 .

\subsubsection{Burner Selection and modification:}

Tests were performed in the SBS using a B\&W DRB- $4 Z^{\mathrm{TM}}$ burner. The burner was rated at $5 \mathrm{MBtu} / \mathrm{hr}$ and has been designed for staged combustion operation. The burner has been modified to receive oxygen in the coal nozzle through a lance or through the transition zone of the burner. Three lances were fabricated for optimization.

\subsection{Coal Characteristics}

The testing was performed in the SBS using a PRB coal purchased from DTE Company. The coal analysis was performed by ISGS, and the results are shown below:

\begin{tabular}{|l|c|}
\hline Moisture (As Received) & $26.85 \%$ \\
\hline Ash (dry) & $6.29 \%$ \\
\hline Volatile (dry) & $47.20 \%$ \\
\hline Carbon (dry) & $72.21 \%$ \\
\hline Hydrogen (dry) & $5.00 \%$ \\
\hline Nitrogen(dry) & $0.92 \%$ \\
\hline Sulfur (dry) & $0.41 \%$ \\
\hline BTU (dry) & 12,505 Btu/lb \\
\hline
\end{tabular}




\subsection{Test Matrix Description}

Two main sets of tests were performed in this quarter, with a total of nine days of experimental data recorded:

1. Optimization of oxygen injection in the primary combustion zone

This first series of tests was performed as a preliminary step to help us gain experience in introducing oxygen into the primary air zone safely and to prepare the way for full oxygen firing. The oxygen in the primary zone could be added through an Oxynator ${ }^{\mathrm{TM}}$ into the primary air line (premixing of oxygen in flue gas and pulverized coal), or at the burner through a lance or through the transition zone (annular room around the coal pipe).

2. Full-oxy combustion with flue gas recirculation: overall operation of the primary, secondary and overfire air ports with oxygen-enriched flue gas recirculation.

This second series of test is of course the main objective of this experimental campaign, enabling the measurement of combustion performances in $\mathrm{O}_{2} / \mathrm{CO}_{2}$ conditions.

\section{TASK 3: TECHNO-ECONOMIC STUDY}

The techno-economic study has been initiated in the previous reporting period and has been refined in the current reporting period with all the details needed to perform accurate calculations. Some first calculations have been initiated and will be reported in the next quarterly report.

The following sub-sections describe the final selection of cases to be evaluated in this study (plant size, equipment, type...) and the details of cost model to be used to perform the economics calculations.

\subsection{Case Study Definition: Process Cases of techno-economic analysis}

As described in a preliminary table shown in the previous quarterly report, the technoeconomics task of the project assesses the economic characteristics of the Oxygen Enhanced Combustion (OEC) process (series 3\&4) for power generation, both for new and retrofit units. This technology is compared to the conventional air blown PC plants, with (series 2) and without (series 1) $\mathrm{CO}_{2}$ separation, and the IGCC plants (series 5).

The impact of the plant size on the economics is considered. For retrofit applications, plants size ranging from small units (50MWe) to larger ones (250 and 500MWe) are considered. For new plants assessment, only larger units (250 and 500MWe) are considered given the current trends in utility industry.

The flue gas cleaning items considered in the cost analysis have to be consistent for every case analyzed, enabling to reduce the pollutant emission to the same level for all cases considered. In the case of retrofit, (OEC, air-blown), the cost analysis will only consider those components in an existing plant that must be modified and new components that need to be added (see Table 1). The net expense or benefit for OEC retrofit will thus be determined. For new plants (OEC, air-blown PC, IGCC), all of the necessary components of the plant will be considered in the techno-economic study. 
Table 2 lists the boiler equipments that are being considered for the cost analysis of series 2 (air-fired PC boiler with $\mathrm{CO}_{2}$ capture via MEA) and 3 (O2-fired PC boiler with flue gas recirculation).

Note that:

o No $\mathrm{NO}_{\mathrm{x}}$ capture device is needed for OEC units since experimental test have proven that $\mathrm{NO}_{\mathrm{x}}$ emissions are very low in $\mathrm{O}_{2} / \mathrm{CO}_{2}$ combustion processes.

o Lime spray dryer (LSD) will be considered as the dry FGD method (other method include LIFAC, or lime duct injection)

o The particulate removal system (ESP) is expected to already equip most of the existing units, thus will not be considered as an equipment to be added in case of retrofit applications, neither for air-blown nor for $\mathrm{O}_{2}$-blown units. In the case of oxygen-fired unit, the ESP may have to work in different operating conditions (lower flue gas volume if no recirculation or installed after the recirculation point, higher particulate concentration, higher moisture content if wet recirculation etc...). However, an upgrade is supposed to be sufficient to have the existing ESP working, without any requirement for investing in a new unit.

\begin{tabular}{|c|c|c|}
\hline & Retrofit plants & New plants \\
\hline $\begin{array}{l}\text { Air-blown units with } \mathrm{CO}_{2} \\
\text { separation (series 2) }\end{array}$ & $\begin{array}{l}\mathrm{CO}_{2} \text { capture (MEA), } \\
\mathrm{SO}_{2} \text { capture (dry FGD), } \\
\mathrm{NO}_{\mathrm{x}} \text { capture (SCR), } \\
\mathrm{Hg} \text { capture (PACI) }\end{array}$ & $\begin{array}{l}\text { All boilers components including } \\
\text { post-treatment items: } \\
\text { Particulate capture (ESP) } \\
\mathrm{CO}_{2} \text { capture (MEA), } \\
\mathrm{SO}_{2} \text { capture (dry FGD), } \\
\mathrm{NO}_{x} \text { capture (SCR), } \\
\mathrm{Hg} \text { capture (PACI) }\end{array}$ \\
\hline $\begin{array}{l}\mathrm{O}_{2} \text {-blown units }(\mathrm{OEC}) \\
\text { with flue gas recirculation } \\
\text { (series } 3 \text { ) }\end{array}$ & $\begin{array}{l}\mathrm{O}_{2} \text { production (ASU), } \\
\mathrm{SO}_{2} \text { capture (dry FGD), } \\
\mathrm{Hg} \text { capture (PACI) }\end{array}$ & $\begin{array}{l}\text { All boilers components including } \\
\mathrm{O}_{2} \text { production (ASU) \& post- } \\
\text { treatment items: } \\
\text { Particulate capture (ESP) } \\
\mathrm{SO}_{2} \text { capture (dry FGD), } \\
\mathrm{Hg} \text { capture (PACI) }\end{array}$ \\
\hline
\end{tabular}

Table 2: Items considered in cost comparison

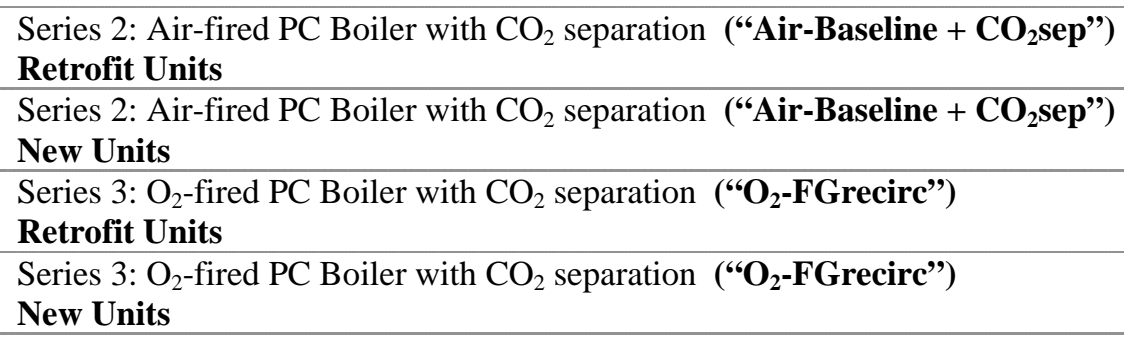


Table 3 summarizes the final specification of the various cases that are considered for the techno-economic analysis and comparison.

\begin{tabular}{|c|c|}
\hline 1. Air-fired PC Boiler w/o $\mathrm{CO}_{2}$ separation & (“Air-Baseline") \\
\hline Plant Size & Existing Plant: 50, 250, 500 MWe \\
\hline Flue Gas Treatment & Existing Plant: ESP \\
\hline 2. Air-fired PC Boiler with $\mathrm{CO}_{2}$ separation & (“Air-Baseline + $\mathrm{CO}_{2}$ sep”) \\
\hline \multirow[t]{2}{*}{ Plant Size } & 50, 250, $500 \mathrm{MWe}$ \\
\hline & 250, $500 \mathrm{MWe}$ \\
\hline \multirow[t]{2}{*}{ Flue Gas Treatment } & Items to be added for retrofit: dry FGD, SCR, PACI, MEA \\
\hline & Items required in new plant: ESP, dry FGD, SCR, PACI, MEA \\
\hline 3. $\mathrm{O}_{2}$-fired $\mathrm{PC}$ with $\mathrm{FG}$ recirculation & (“O ${ }_{2}$-FGrecirc”) \\
\hline \multirow[t]{2}{*}{ Plant Size } & 50, 250, $500 \mathrm{MWe}$ \\
\hline & 250, $500 \mathrm{MWe}$ \\
\hline \multirow[t]{2}{*}{ Flue Gas Treatment } & Items to be added for retrofit: ASU, dry FGD, PACI \\
\hline & Items required in new plant: ESP, ASU, dry FGD, PACI \\
\hline 4. $\mathrm{O}_{2}$-fired PC w/o FG recirculation for new plant only & (“O2-noFGrecirc”) \\
\hline Plant Size & New Plant: $\quad 250,500 \mathrm{MWe}$ \\
\hline Flue Gas Treatment & Items required in new plant: ESP, ASU, SCR, dry FGD, PACI \\
\hline 5. IGCC & (“IGCC”) \\
\hline Plant Size & 250, 500MWe \\
\hline Flue Gas Treatment & Items required in new plant: flue gas cleanup for IGCC (TBD) \\
\hline
\end{tabular}
Table 3: Process Cases of the techno-economic analysis

\subsection{Process simulation}

The process simulation studies provide mass and energy balances of the main stream of the plant. The flow diagram to be simulated have been described in the previous quarterly report. Following are some more details about process areas to be simulated.

For the conventional PC plant, four main process areas are simulated: $\mathbf{O}$ boiler system, 2 steam turbine generator, 3 flue gas cleaning, and $\mathbf{4} \mathrm{CO}_{2}$ separation process. The OEC process involves the former process areas $(\mathbf{2} 2 \& \mathbf{3}$ and the air separation unit (ASU).

For each main process area, several major components are considered in the simulation studies. They are:

\subsubsection{Boiler system}

Coal and Air $/ \mathrm{O}_{2}$ feeding

Boiler

Super heater, re-heater, economizer and air pre-heater

Wet flue gas re-circulation (wet FGR), and dry FGR in some cases

\subsubsection{Steam turbine generator}

Steam turbines

Heat Recovery Steam Generator (HRSG)

Cooling water system

Feed water and miscellaneous systems 


\subsubsection{Flue gas cleaning}

ESP

Dry FGD

SCR

Carbon injection for Hg removal (APCI)

\subsubsection{AME process for $\mathrm{CO}_{2}$ separation}

Absorber and stripper

$\mathrm{CO}_{2}$ compression

\subsection{Auxiliary power modeling}

Certain process items of the power plant, such as pumps and conveyors consume significant amounts of electricity. These auxiliary power requirements reduce the net power output of the plant, and thus affect the generation cost.

The net power generation is defined as the gross power generation minus the auxiliary power use, and the net plant efficiency is defined as the net power generation divided by the total thermal input. The following auxiliary power requirements are then used for estimating the electricity generation cost.

Auxiliary power consumptions are mainly related to the process variables such as air, flue gas, and water flow rates. They are available for certain plant sizes in a few references. The relationship of the auxiliary power consumptions can be functions of the process variables of the system. Based on available data from literature, correlation formulas have been developed. The followings are the main auxiliary power load items which are included in cost estimations (auxiliary power consumptions will be correlated to the variables in the parenthesis):

\subsubsection{Combustion and generation:}

$\checkmark$ Coal handling ( coal feed rate)

$\checkmark$ Pulverizers ( coal feed rate and coal size)

$\checkmark$ Primary air fans ( primary air flow rate)

$\checkmark$ Forced Draft fans ( air flow rate)

$\checkmark$ Induced draft fans ( $\sim$ flue gas flow rate)

$\checkmark$ Seal air blowers

$\checkmark$ Steam turbine auxiliaries

$\checkmark$ Condensate pumps ( $\sim$ condensate from cooling tower)

$\checkmark$ Circulating water pumps ( circulating water flow rate)

$\checkmark$ Cooling water pumps ( $\sim$ cooling water flow rate)

$\checkmark$ Ash handling ( ash production)

$\checkmark$ Miscellaneous balance of plant ( control systems, lighting, HVAC etc)

$\checkmark$ Transformer loss 


\subsubsection{Flue gas cleaning:}

$\checkmark$ ESP

$\checkmark$ FGD

$\checkmark$ SCR

Sorbent handling and preparation (sorbent feeding rate)

$>$ Pumps and agitators (sorbent feeding rate)

> Byproduct handling (byproduct production)

$\checkmark \mathrm{Hg}$

\subsection{3 $\quad \mathrm{CO}_{2}$ separation (Amine process)}

$\checkmark$ MEA unit (flue gas flow rate)

$\checkmark \mathrm{CO}_{2}$ compressor $\left(\mathrm{CO}_{2}\right.$ mass flow rate)

\subsection{4 $\quad$ Air separation unit (ASU)}

\subsection{Cost model: Capital and O\&M cost modeling}

The cost model used to complete this economics assessment and whose overall principles have been described in the previous quarterly report has been defined in more detailed in the current quarter.

\subsubsection{Direct capital cost.}

Classification of process areas, Table 4, for estimating capital costs is based on a reference plant developed in a DOE report (reference 1). Only gas turbine generator is not relevant to this study (steam turbine plants).

The remaining 13 areas, related to the conventional PC plant, are listed in Table 3 in black color. In addition, other process areas, specific to this study, are listed in red in the table:

- Some additional flue gas treatment devices $\left(\mathrm{NO}_{\mathrm{x}}, \mathrm{SO}_{\mathrm{x}}, \mathrm{Hg}\right.$ removal) are being considered,

- The 14-16 processes are related to the $\mathrm{CO}_{2}$ separation and the OEC process.

\begin{tabular}{|l|l|}
\hline 1. Coal handling & 7. Steam turbine generator \\
\hline 2. Coal preparation \& feed & 8. Cooling water system \\
\hline 3. Feed water \&misc. & 9. Ash/Spent sorbent handling system \\
\hline 4. PC boiler \& accessories & 10. Accessory electric plant \\
\hline 5. Flue gas cleaning & 11. Instrumentation \&control \\
ESP & 12. Improvements to site \\
Dry FGD & 13. Buildings and structures \\
SCR & 14. $\mathrm{CO}_{2}$ separation \\
Mercury removal & 15. ASU $\left(\mathrm{O}_{2}\right.$ production $)$ \\
\hline 6. HRSG, ducting and Stack & 16. Flue gas recirculation \\
\hline
\end{tabular}

Table 4: Classification of process areas

Each process area listed above is composed of its sub-areas, and sub-sub areas (individual equipments). The direct capital cost can be determined at each level. 
Table 5 provides an example of four data levels for a steam turbine generator. The process area of the steam turbine generator has 5 sub-areas, and for the $1^{\text {st }}$ sub-areas (8.1) there are 7 equipments.

\begin{tabular}{|c|c|c|c|}
\hline Plant & Process area & Sub-area & Equipment \\
\hline \multirow[t]{7}{*}{$\begin{array}{l}\text { Power } \\
\text { plant }\end{array}$} & $\begin{array}{l}8 \text { Steam turbine } \\
\text { generator }\end{array}$ & $\begin{array}{l}\text { 8.1 Steam TG \& } \\
\text { Accessories }\end{array}$ & 8.1.1 Turbine generator \\
\hline & $\begin{array}{l}9 \text { Ash/Spent sorbent } \\
\text { handling system }\end{array}$ & $\begin{array}{l}8.2 \text { Turbine plant } \\
\text { auxiliaries }\end{array}$ & $\begin{array}{l}\text { 8.1.2 Bearing lube oil } \\
\text { coolers }\end{array}$ \\
\hline & $\begin{array}{l}10 \text { Accessory } \\
\text { electric plant }\end{array}$ & $\begin{array}{l}\text { 8.3 Condenser } \\
\text { \&Auxiliaries }\end{array}$ & $\begin{array}{l}\text { 8.1.3 Bearing Lube oil } \\
\text { conditioners }\end{array}$ \\
\hline & $\cdots$ & 8.4 Steam piping & 8.1.4 Control system \\
\hline & $\cdots$ & 8.9 TG foundations & 8.1.5 Generator coolers \\
\hline & $\ldots$ & & $\begin{array}{l}\text { 8.1.6 Hydrogen seal oil } \\
\text { system }\end{array}$ \\
\hline & $\cdots$ & & 8.1.7 Generator exciter \\
\hline
\end{tabular}

Table 5: Data levels, an example of the steam turbine generator

Due to the availability of data in literature, the cost estimation at the process area level is mostly considered in this study. However, for $\mathrm{CO}_{2}$ separation, flue gas cleaning, flue gas recirculation and ASU process areas, more detailed breakdown costs are estimated.

Due to the plant size effect, the cost data of the individual process areas available in literature have to be scaled-up and/or scaled-down to the desired plant sizes considered in this study. Because cost data are not often linearly correlated to the plant size, efforts will be made to assure that the most accurate cost-size correlations are estimated based on the existing literature data. Other process parameters, such as the pollutant concentration, may also affect the costs. Several methods to obtain these cost correlations are listed below.

- The relationships of cost vs. process variables are regressed from data in literature and using the following formula:

$\mathrm{Cn}=\mathrm{f}(\mathrm{x} 1, \mathrm{x} 2, \ldots)$;

$\mathrm{n}=1, . .16$, process areas;

$\mathrm{x} 1, \mathrm{x} 2, \ldots=$ plant capacity, process parameters,...

- The exponential scaling factors of process areas are developed based on USDOE's 400 MWe reference plant, EPRI’s 250 MWe example plant, and other available data.

- The detailed cost estimations of FGD, SCR, $\mathrm{Hg}$ removal and $\mathrm{CO}_{2}$ separation are available in DOE, EPRI, US-EPA publications.

- The relationship of ASU cost (capital and O\&M) vs. the plant size is based on the information provided by American Air Liquide.

- For boiler, turbine, cooling systems, the size impact of their major equipments (boiler, steam turbine, cooling tower) can be approximately used for their affiliated process area. 
These approaches for estimating the costs of process areas for various plant sizes and other process parameters will be combined to determine the capital costs.

\subsubsection{O\&M cost.}

Cost and expenses associated with operating and maintaining of a plant include:

- Operating labor, administrative and support labor;

- Maintenance labor and materials,

- Consumables,

- Fuel cost.

Operating and supportive labor can be estimated on the basis of the number of operating jobs (OJ) required to run the plant. The OJ data are not necessarily related to the plant size, but rather depend on the number of units under operation. Therefore, the representative OJ data of the major plant areas, which is available in the literature, can be used regardless of the plant size.

Annual cost of maintenance labor and materials is estimated as a percentage of the installed capital cost. The percentage varies widely, depending on the specific processing conditions and the type of design for each process area. The representative percentage is selected for each process area from literature.

Consumables materials include water, chemicals, and other consumables:

$\Rightarrow$ Water makeup for steam cycle and miscellaneous use

$\Rightarrow$ Water treating chemicals

$\Rightarrow$ Waste water treating chemicals

$\Rightarrow$ Steam

$\Rightarrow$ Lime

$\Rightarrow$ SCR catalyst

$\Rightarrow$ Ammonia

$\Rightarrow$ Activated carbon

$\Rightarrow$ Amine

Results from the process simulation studies provide the mass flows of the consumables listed above. Their costs can thus be estimated according to their unit market prices.

PRB coal is considered as the fuel in this study.

\subsubsection{Data collection}

An extensive literature review has been conducted and most of the information required for performing the techno-economic analyses has been collected. A list of published reports that will be used for estimating auxiliary powers and costs associated with various process areas is presented in the REFERENCES chapter of this report. 


\section{RESULTS AND DISCUSSION}

As described in the "Experimental" section of this report, the performance of experimental tests has been initiated in the current quarter. Some first experimental results are thus available and reported hereafter, providing some preliminary trends to be confirmed and optimized in the next quarter.

Some data related to the project management are also reported in the following "Project Schedule" and "Financial Status" subsections.

\section{TASK 2: COMBUSTION AND EMISSIONS PERFORMANCE OPTIMIZATION}

As reported in the previous chapter "EXPERIMENTAL", two weeks of tests have been performed in the current quarter, leading to the first experimental data related to $\mathrm{O}_{2} / \mathrm{CO}_{2}$ combustion ever obtained on a 1.5MWth boiler featuring all components of an industrial fullscale PC boiler design.

The preliminary results recorded during this testing period are reported below. Some interesting characteristics and trends of $\mathrm{O}_{2} / \mathrm{CO}_{2}$ combustion as compared to air-combustion are already highlighted, although a deeper analysis is required to extract all possible information from those experimental data. The data analysis will be completed in the future, with additional tests measurements provided by the next tests period (one more week scheduled in October 2003 for combustion optimization) and it will be reported in the next quarterly reports.

Below are some results and trend recorded on the two main sets of tests performed in this quarter:

1. Optimization of oxygen injection in the primary combustion zone

2. Full-oxy combustion with flue gas recirculation: overall operation of the primary, secondary and overfire air ports with oxygen-enriched flue gas recirculation.

\subsection{Optimization of oxygen injection in the primary combustion zone}

The primary air is primarily used as a conveyor gas picking up the pulverized coal from the coal feeder and carrying it through the burner. It also provides 15 to $20 \%$ of the overall oxygen required to complete the combustion in pulverized coal units.

In full-oxy configuration, the idea consists of replacing $100 \%$ of the combustion air by pure oxygen diluted in recirculated flue gas. The replacement of secondary and tertiary air is relatively straightforward once the recirculation capability and the oxygen delivery system have been installed in the facility. However, the primary air replacement is more complex since the fuel (pulverized coal) presence brings safety issues to be carefully addressed.

In order to test the oxygen injection system in the primary zone and to select the best practice for further full oxygen firing, a first set of tests was performed in which oxygen was injected ONLY in the primary air zone, air remaining the only oxidant in the secondary and tertiary combustion zones.

Three main processes were tested to inject oxygen in the primary air zone: 
$\checkmark$ A small lance installed at the center of the burner

$\checkmark$ The transition zone: an annular space around the coal pipe, at the burner level

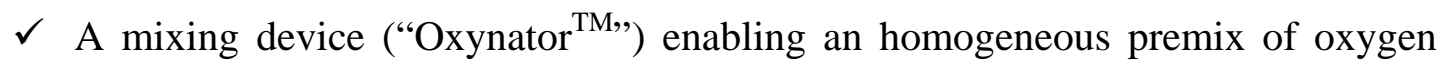
into the primary air or flue gas.

The first tests performed consisted of $\mathrm{O}_{2}$-enriching the primary air to make sure the three oxygen injection techniques were working as expected: the air enrichment tests with a large lance at the center of the burner, through the transition zone or by premixing in the primary air enrichment via an Oxynator produced very stable flame. We then substituted the primary air with flue gas and oxygen. Initially, we introduced oxygen through the lance, and later introduced some oxygen via the Oxynator through the primary air/flue gas line. These tests helped us to gain experience in introducing oxygen into the primary air zone safely and prepare the way for full oxygen firing.

\subsection{Full Oxy-firing with flue gas recirculation}

As mentioned before, these tests were performed after we gained enough operating experience in switching from air firing to flue gas and oxygen in the primary air line.

\subsubsection{Operating conditions and air- $\mathrm{O}_{2}$ switching procedure}

We maintained the mass flow rate of the combustible and oxidizers in the combustion zone when air was switched to flue gas and oxygen.

The oxygen to the secondary air and overfire air port was introduced through the Oxynator.

The switching of primary air to flue gas was initially performed with addition of oxygen only through a lance at the burner. After the unit was operated on flue gas, then some oxygen was introduced in the primary air line with the remainder introduced at the burner.

\subsection{2 $\underline{\text { Results and discussion }}$}

We obtained a stable flame, attached at the throat, and flame shape was similar to air firing. The oxygen flame could be seen visually in the middle of flame (video camera installed). We decided to fabricate an oxygen lance to spread the gas more rapidly. The nozzle was fabricated and ready for testing. The baseline $\mathrm{NO}_{\mathrm{x}}$ was $0.42 \mathrm{lb} / \mathrm{MMBtu}$ (high for this burner, typically 0.15 ) but was reduced to $0.125 \mathrm{lb} / \mathrm{MMBtu}$ with oxygen enriched flue gas firing $(70 \%$ reduction).

One area of concern was air infiltration into the flue gas line, and we initially observed only $55 \% \mathrm{CO}_{2}$ at $3.5 \%$ boiler exit oxygen level. The infiltrated air was approximately $10 \%$ of the total boiler gas flow rate (air, oxygen, flue gas, coal). Air infiltration has been discussed as an issue for commercial application of this technology, and we decided to pursue tests to identify the sources of the air leaks and the potential remedy. The condensing Heat Exchanger $\left(\mathrm{CH}_{\mathrm{x}}\right)$ is operating under slightly positive pressure, and no air leak is expected from it. The boiler is balanced draft and operates under slightly negative pressure (-0.5 inch of water). Air leaks should be minimal. The main sources of air leaks are suspected to be the I.D. fan, baghouse and scrubber that are operating under higher negative pressures. To assist with identifying the largest source of air leaks, we measured the oxygen at the convection pass exit, dry scrubber exit, 
baghouse exit, and the flue gas entering the F.D. fan under the same conditions. The test identified the I.D. fan as the largest leak following by the scrubber and baghouse. After the unit inspection and fixing many holes/leaks, the air leakage has been reduced to half of the original, approximately $5 \%$ of the total boiler gas flow rate (air, oxygen, flue gas, coal). This level of air leakage is a good representative of potential air leaks in commercial boiler retrofits from the ESP, air heater, etc. There are alternative boiler operating procedures that could be employed to reduce the air leaks. Up to $70 \%$ of $\mathrm{CO}_{2}$ was achieved. 


\section{PROJECT SCHEDULE}

The current status of the project tasks and sub-tasks is displayed below, followed by a short description of the work to be performed in the next quarter (Oct-Dec. 2003).

\subsection{Status of the project tasks and sub-tasks}

The sub-tasks completed in previous reporting period (bold \& black), completed in the current reporting period (bold \& blue), currently in progress or soon to be ongoing, together with their deadlines, are:

\section{Deadline $\quad \underline{\text { Status }}$}

\section{Task 1: Site Preparation}

Task 1.1: $\quad$ List of required modifications $\quad$ March 30, 2003 - Completed

Task 1.2: $\quad$ Conceptual design of SBS adaptations April 15, 2003 - Completed

Task 1.2: $\quad$ Technical design of SBS adaptations $\quad$ April 30, 2003 - Completed

Task 1.3: Implementation of SBS adaptations July 30, 2003 - Completed

Task 1.4: System shake-down $\quad$ August 1, 2003 - Completed

Task 2: Test Performance

Task 2.1: $\quad$ Test matrix definition

Sept. 15, 2003 - Completed

Task 2.2: $\quad$ Tests performance

Dec. 15, 2003 - In Progress

Task 2.3\&2.4: Test analysis \& Report

March 15, 2004 - In Progress

Task 3: Techno-Economic Study

Task 3.1: $\quad$ Cases Specification

Task 3.2: Methodology Definition

Task 3.3: $\quad$ Process Simulation \& Cost Estimation

Task 3.4: $\quad$ Results analysis \& Report
Sept. 15, 2003 - Completed

Aug. 30, 2003 - Completed

March 30, 2004 - In Progress

June 30, 2004 - Future

Table 6: Project Schedule

\subsection{Next quarter sub-tasks}

During the next quarter (October $1^{\text {st }}$ to December $31^{\text {th }}$ 2003), the following activities will be performed:

- Tests Performance (task 2) will be completed in the limit of funds already allocated $(\$ 485 \mathrm{k})$. The current schedule is to perform one week of combustion optimization tests in October, tentatively scheduled for the week of October 13th, and dry scrubber/mercury measurements during November.

- The technico-economical study (task 3) will continue and provide the first results $\left(\mathrm{O}_{2}\right.$ based system compared to regular PC boiler). 


\section{FINANCIAL STATUS}

Tables 7 and 8 show the financial status of the report to-date. An amount of $\sim \$ 388 \mathrm{k}$ has been spent by the main contractor in the reporting period $\left(Q_{3}, 2003\right)$, including $\sim \$ 40 \mathrm{k}$ of direct labor, $\sim 3 \mathrm{k}$ in travel, $\sim \$ 12 \mathrm{k}$ of material \& equipment related to the upgraded oxygen supply system and coal supply, 261k of contractual (site preparation and first test series on pilot boiler) and $\sim \$ 72,000$ of indirect charges. To date, \$540k have been spent and reported in the project. The cost related to the tests performed in September will be reported in the next quarter, along with the expenses related to an additional week of tests to be performed in October and to half of the economical study currently in progress. The project proceeds according to the planning. No invoice to DOE was yet issued. The ASAP software was received on October 20, 2003 and will soon be used for reimbursement requests.

\begin{tabular}{|c|c|c|c|c|c|c|c|}
\hline \multicolumn{4}{|c|}{ 10. Transactions: } & $\begin{array}{l}\text { I } \\
\text { Previously } \\
\text { Reported }\end{array}$ & \multicolumn{2}{|c|}{$\begin{array}{l}\text { II } \\
\text { This } \\
\text { Period }\end{array}$} & $\begin{array}{l}\text { III } \\
\text { Cumulative }\end{array}$ \\
\hline \multicolumn{4}{|c|}{ a. Total outlays } & $\$ 153,728.14$ & \multicolumn{2}{|c|}{$\$ 388,133.49$} & $\$ 138,835.18$ \\
\hline \multicolumn{4}{|c|}{ b. Recipient share of outlays } & $\$ 153,728.14$ & \multicolumn{2}{|c|}{$\$ 388,133.49$} & $\$ 138,835.18$ \\
\hline \multicolumn{4}{|c|}{ c. Federal share of outlays } & $\$ 0$ & & $\$ 0$ & $\$ 0$ \\
\hline \multicolumn{4}{|c|}{ d. Total unliquidated obligations } & & & & $\$ 0$ \\
\hline \multicolumn{4}{|c|}{ e. Recipient share of unliquidated obligations } & & & & $\$ 0$ \\
\hline \multicolumn{4}{|c|}{ f. Federal share of unliquidated obligations } & & & & $\$ 0$ \\
\hline \multicolumn{4}{|c|}{ g. Total Federal share (Sum of lines c and f) } & & & & $\$ 0$ \\
\hline \multicolumn{4}{|c|}{ h. Total Federal funds authorized for this funding period } & & & & $\$ 485,268.00$ \\
\hline \multicolumn{4}{|c|}{ i. Unobligated balance of Federal funds (Line h minus line g) } & & & & $\$ 485,268.00$ \\
\hline \multirow[t]{2}{*}{$\begin{array}{l}\text { 11. Indirect } \\
\text { Expense }\end{array}$} & \multicolumn{6}{|c|}{ a. Type of Rate (Place "X" in appropriate box) } & $\square$ Fixed \\
\hline & $\begin{array}{l}\text { b. Rate } \\
\text { see attachme }\end{array}$ & $\begin{array}{l}\text { c. Base } \\
\text { see attach }\end{array}$ & & \multicolumn{2}{|c|}{$\begin{array}{l}\text { d. Total Amount } \\
\qquad \mathbf{1 3 8 , 8 3 5 . 1 8}\end{array}$} & \multicolumn{2}{|c|}{ e. Federal Share } \\
\hline
\end{tabular}

Table 7: Financial situation to-date.

\begin{tabular}{|c|c|c|c|c|}
\hline Indirect Expenses & Rate & Base & $\begin{array}{c}\text { Indirect expense } \\
\text { charged to the } \\
\text { project }\end{array}$ & $\begin{array}{c}\text { Federal share } \\
\text { for indirect } \\
\text { expense }\end{array}$ \\
\hline Labor Overhead & $87.94 \%$ & $\begin{array}{c}\text { Total Direct Labor Costs \$100,032.00 } \\
\text { Total Direct Project Costs } \\
\text { and Overhead Costs } \$ 490,994.59\end{array}$ & $\$ 87,968.14$ & $\$ 0$ \\
General\&Administrative & $10.36 \%$ & $\$ 50,867.63$ & $\$ 0$ \\
\hline \multicolumn{2}{|l}{ Total Indirect Expenses } \\
\hline
\end{tabular}

Table 8: Indirect Expenses (details)

\section{TASK 5: PROJECT MANAGEMENT \& REPORTING}

The sub-contract between American Air Liquide and Babcock and Wilcox has been finalized in June 2003. 2003.

The sub-contract between American Air Liquide and ISGS will be finalized in October 


\section{CONCLUSION}

The project is to-date advancing according to the plan, technically and financially.

At the end of this first budget period (October 1, 2002 through September 30, 2003, and actually eight months of effort following the agreement signature in February 2003), the Site Preparation (Task 1) is completed, two weeks of tests have been performed (Task 2) and the Techno-Economic Study (Task 3) is in progress.

As far as the milestones of the project, the two first ones have already been completed as per the initial schedule:

$\checkmark$ On August 2003, the Site Preparation (Task 1) of 5 million Btu/hr B\&W's Small Boiler Simulator (SBS) enabling delivery of recycled flue gas and oxygen to the boiler to allow oxygen-enhanced combustion tests as been completed, along with the boiler equipment with appropriate sensors and controls. The modifications required to enable the complete air replacement with oxygen and recirculated flue gases have been implemented, all instrumentation insuring accurate data collection and analysis installed, and the coal along with its feeding system prepared. The entire system has been shakedown mid August 2003 enabling Task 2 initiation.

$\checkmark$ On September 2003, the Test Definition including oxidant streams a specification has been completed, and the analyses of a representative sample of PRB coal for testing performed.

As of today, the third milestone (Test Performance completion, due by Dec 2003) is on schedule: two weeks of tests have been completed and the feasibility of $100 \%$ air replacement by $\mathrm{O}_{2}$-enriched flue gas on 1.5MW coal-fired boiler demonstrated. Air infiltrations have been reduced from an initial level of approximately $10 \%$ of the total stoichiometry to a final level of approximately 5\%, thus increasing the initial $\mathrm{CO}_{2}$ content in flue gas from $15 \%$ in air-fired conditions to $55 \%$ in full-oxy conditions with $10 \%$ air infiltration, and to eventually $70 \%$ while reducing the air in-leakage down to 5\%. Alternative boiler operating procedures are expected to reduce even more the air infiltration to achieve higher $\mathrm{CO}_{2}$ concentration in flue gas for further sequestration or reuse. The $\mathrm{NO}_{\mathrm{x}}$ emissions have been shown considerably lower in $\mathrm{O}_{2}$-fired conditions than in air-baseline, the reduction rate averaging $70 \%$.

The Techno-Economic Study (Task 3) is in progress (completion due June 2004): a detailed description of power generating units to be compared as been performed, including airfired pulverized coal (PC) units with and without $\mathrm{CO}_{2}$ separation, oxygen-fired PC units with or without flue gas recirculation, and IGCC units. Plant capacity and equipment have been listed, the methodology to be followed carefully described and the first heat and mass balance along with cost calculations are currently being performed.

In the next quarter, an additional week of tests is scheduled mid October 2003 for combustion parameter optimization, and additional days of operation will be dedicated to mercury emission measurement and heat transfer characterization. Depending on the funds allocation, mercury emission and heat transfer measurements may also be scheduled in that period. The first part of the Techno-Economic will be completed by December 2003, the second one depending on funds allocation. 


\section{REFERENCES}

List of published reports that will be used for performing the techno-economic analyses (estimation of auxiliary powers and costs associated with various process areas):

\section{CONVENTIONAL PC POWER PLANT}

(1) Gilbert/Commonwealth Inc., Clean Coal Reference Plants: Pulverized Coal Boiler with Flue Gas Desulfurization, DE-AM21-94MC311 66, September 1995

(2) Office of Fossil Energy, US DOE, Market Based Advanced Coal Power Systems, DOE/FE-0400, May 1999

(3) United Engineers \& Constructors Inc, Total Generation Cost: Coal and nuclear Plants, DOE EY-76-C-02-2477, February 1979

(4) EIA, Electric plant cost and power production expenses 1988, DOE/EIA-0455, August 1990

(5) DOE/EIA , Steam-electric plant construction cost and annual production expenses, 1977

\section{CO2 REMOVAL PROCESS}

(6) EPRI, Evaluation of Innovative Fossil Fuel Power Plants with CO2 Removal, Interim Report 1000316, December 2000

(7) EPRI, Updated Cost and Performance Estimates for Fossil Fuel Power Plants with CO2 Removal, Interim Report 10004483, December 2002

\section{FGD PROCESS}

(8) United Engineers and Constructions, Inc., Economic Evaluation of Flue Gas Desulfurization Systems, EPRI GS-7193, February 1991

(9) Srivastava R K, Controlling SO2 Emissions: A review of the Technologies, EPA/600/R00/093, November 2000

\section{SCR PROCESS}

(10) Foerter D and Jozewicz W, Cost of Selective Catalytic Reduction (SCR) Application for NOx Control on Coal-fired Boilers, EPA/600/R-01/087, October 2001

\section{MERCURY REMOVAL PROCESS}

(11) US EPA, Mercury Study Report to Congress, Vol. VIII: An Evaluation of Mercury Control Technologies and Costs, EPA-452/R-97-010, December 1997 


\section{IGCC PLANT}

(12) Scott Chen, Subhash Bhagwat, Massoud Rostam-Abadi, Techno-Economic Studies of Illinois Coal in Future Power production processes. ICCI Project No: 01-1/2.3C-1, October, 2002

(13) Destec Gasifier IGCC Based Cases, PED-IGCC-98-003, Prepared by EG\&G, Sept. 1998, revised June 2000.

(14) Economic Assessment of the Impact of Plant Size on Coal Gasification-Combined Cycle Plants, Prepared by Fluor Engineers, Inc. EPRI Report, AP-3084, May 1983. 


\section{LIST OF ACRONYMS AND ABBREVIATIONS}

\begin{tabular}{|c|c|}
\hline AAL & American Air Liquide \\
\hline BSR & Burner Stoichiometric Ratio \\
\hline $\mathrm{B} \& W$ & Babcock and Wilcox \\
\hline $\mathrm{CHx}$ & Condensing Heat Exchanger \\
\hline $\mathrm{COE}$ & Cost of Electricity \\
\hline $\mathrm{DOE}$ & Department of Energy \\
\hline EPA & Environmental Energy Agency \\
\hline EPRI & Electric Power Research Institute \\
\hline ESP & Electrostatic Precipitator \\
\hline FD Fan & Forced Draft Fan \\
\hline FEGT & Furnace Exit Gas Temperature \\
\hline FG & Flue Gas \\
\hline FGD & Flue Gas Desulfurization \\
\hline FGR / RFG & Flue Gas Recirculation / Recycled flue gas \\
\hline $\mathrm{Hg}$ & Mercury \\
\hline HMI & Human Machine Interface \\
\hline HRSG & Heat Recovery Steam Generator \\
\hline ID Fan & Induced Draft Fan \\
\hline IGCC & Integrated Gasification Combined Cycle \\
\hline ISGS & Illinois State Geological Survey \\
\hline LOI & Lost On Ignition (Unburned Carbon in Ash) \\
\hline MEA & Mono ethanol-amine \\
\hline NETL & National Energy Technology Laboratory \\
\hline OEC & Oxygen Enriched Combustion \\
\hline $\mathrm{O} \& \mathrm{M}$ & Operating And Maintenance \\
\hline PA & Primary Air \\
\hline PACI & Pulverized Activated Carbon Injection \\
\hline PC & Pulverized Coal (Boiler) \\
\hline $\mathrm{PO}$ & Primary Oxidant \\
\hline PRB & Powder River Basin \\
\hline SA & Secondary Air \\
\hline SBS & Small Boiler Simulator \\
\hline SCR & Selective Catalytic Reduction \\
\hline SNCR & Selective Non Catalytic Reduction \\
\hline SO & Secondary Oxidant \\
\hline TA & Tertiary Air \\
\hline TBD & To be defined \\
\hline TCR & Total Capital Requirement \\
\hline TO & Tertiary Oxidant \\
\hline ТPC & Total Plant Cost \\
\hline
\end{tabular}


TPI Total Plant Investment

UBC Unburned Carbon in Ash 


\section{APPENDICES}

Appendix A. SBS (SMall BoIler Simulator) In AN OXYGEn Firing Mode ................... 29

APPENDIX B. NEW EQUIPMENT AND DUCT WORK (IN RED) INSTALLED ON THE SBS.............. 30

APPENDIX C. UPDATED MODIFIED OXYGEN SKID AS ANTICIPATED ON JUNE 30 ${ }^{\mathrm{TH}}, 2003 . . . . . .31$ 


\section{Appendix A. SBS (SMAll BoIler Simulator) in AN OXYgen FiRING ModE}

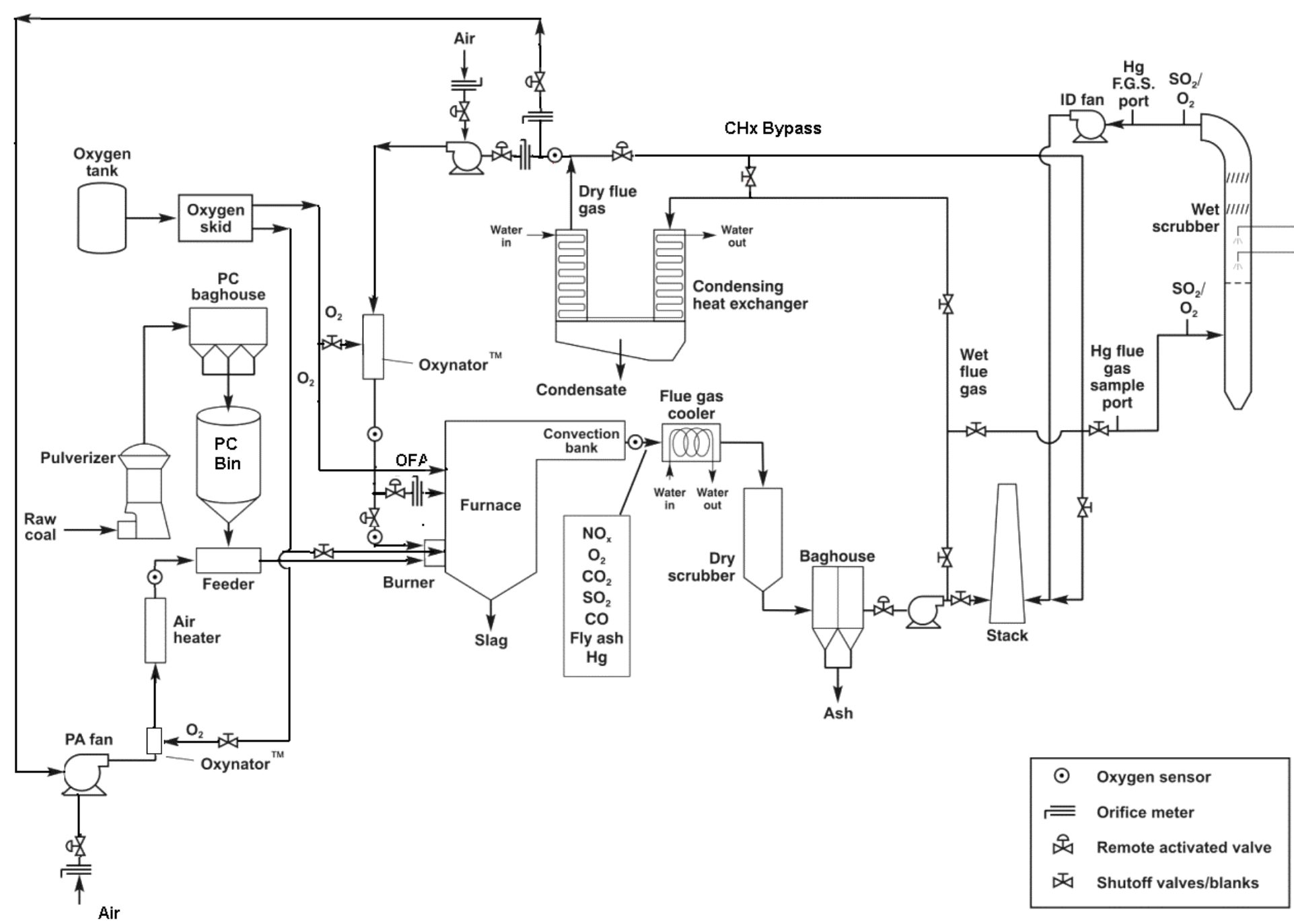

Figure 1: SBS (Small Boiler Simulator) schematics 


\section{Appendix B. NEW EQUIPMENT AND DUCT WORK (IN RED) INSTALLED ON THE SBS}

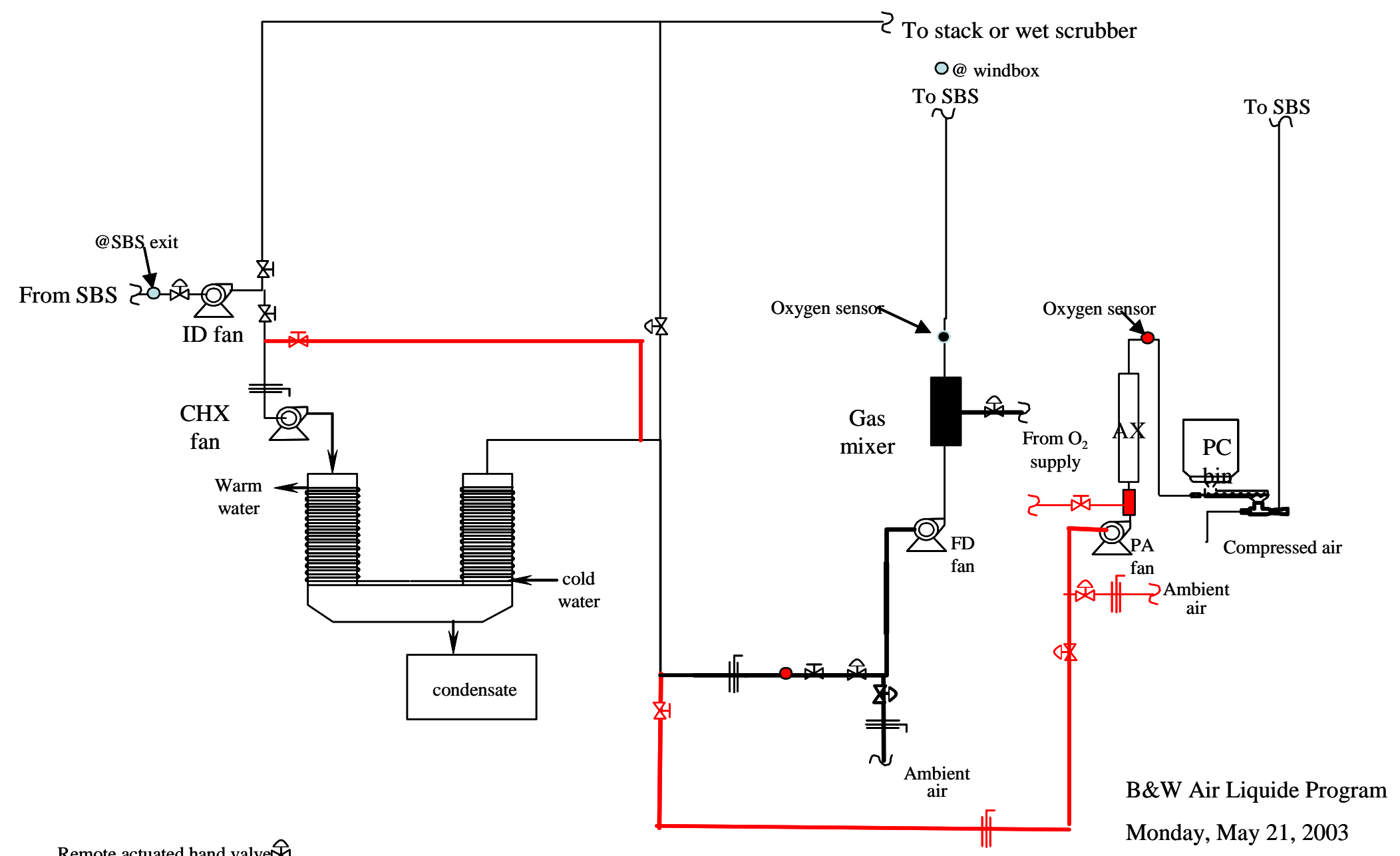




\section{Appendix C. UpDATED MODIFIED OXYGEN SKID}

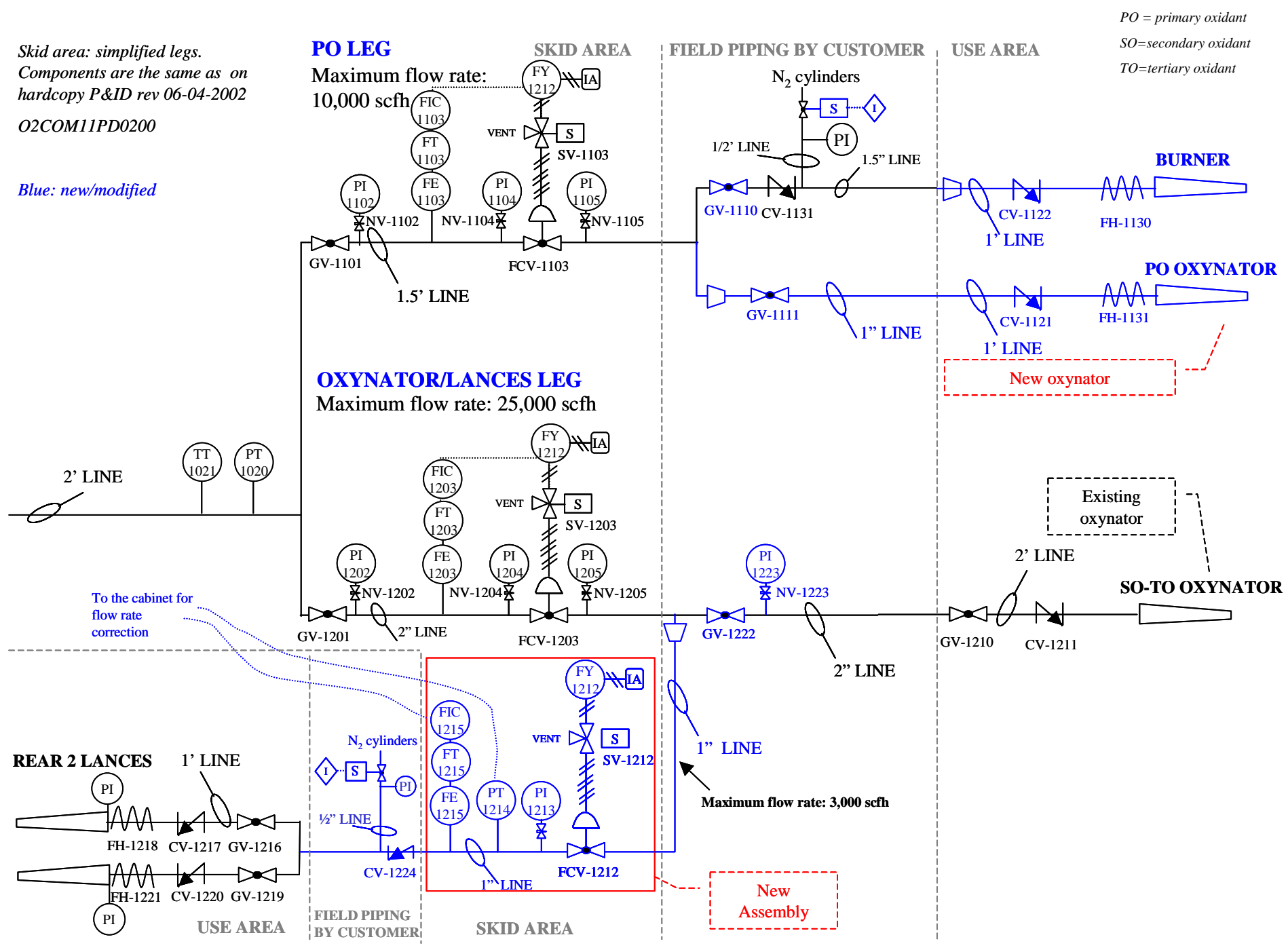

Figure 3: Updated modified Oxygen Skid 